Article

\title{
Inter-Building Effect and Its Relation with Highly Reflective Envelopes on Building Energy Use: Case Study for Cities of Japan
}

\author{
Jihui Yuan * (D), Craig Farnham and Kazuo Emura \\ Department of Housing and Environmental Design, Graduate School of Human Life Science, \\ Osaka City University, 3-3-138, Sugimoto, Sumiyoshi-ku, Osaka 558-8585, Japan; \\ farnham@life.osaka-cu.ac.jp (C.F.); emura@life.osaka-cu.ac.jp (K.E.) \\ * Correspondence: yuanjihui@hotmail.co.jp; Tel.: +81-6-6605-2820
}

Received: 19 September 2017; Accepted: 27 October 2017; Published: 28 October 2017

\begin{abstract}
The built environment with respect to building envelope designs and the surrounding micro-environment significantly affects building energy use. The influence of the inter-building effect (IBE) on building energy use cannot be ignored and thermal properties of building envelopes also largely affect building energy use. In order to evaluate the influence of IBE and its relation with highly-reflective (HR) building envelopes on building energy use, the building energy use under three simulated scenarios was quantitatively analyzed using the building energy optimization software "BEopt" for five cities of Japan. Analysis indicated that when the simulated building is neighbored by other buildings, an envelope coated with HR material is more effective than lowly-reflective (LR) material to reduce building energy use. A simulated single building without surrounding buildings and a LR envelope has the highest building energy use among the three simulated scenarios. This study also showed the influence of IBE on building energy savings is stronger in cities with lower latitudes.
\end{abstract}

Keywords: Japan cities; building energy use; inter-building effect; highly-reflective building envelope; BEopt analysis

\section{Introduction}

The rapidly growing world energy use has already raised concerns over supply difficulties, exhaustion of energy resources, and heavy environmental impacts, such as ozone layer depletion, global warming, climate change, etc. Previous research has indicated that the global contribution from buildings towards energy consumption, both residential and commercial, has steadily increased to between $20 \%$ and $40 \%$ in developed countries, and has exceeded the other major sectors: industrial and transportation [1]. The nation's 114 million households and more than 4.7 million commercial buildings consume more energy than the transportation or industry sectors, accounting for nearly $40 \%$ of total U.S. energy use [2]. Cities represent the highest concentration of energy use; they occupy $2 \%$ of the Earth's surface. However, their inhabitants consume about $75 \%$ of the world's resources [3]. A report showed that buildings account for the largest proportion of energy consumption, with as much as $32 \%$ of total final energy consumption and nearly $40 \%$ of primary energy consumption [4]. The numbers are especially prominent in developed countries. According to the latest report from Ministry of Economy, Trade and Industry (METI), the carbon dioxide emissions from energy consumption in the consumer sector accounts for approximately two-third of the carbon dioxide emissions of Japan [5].

Many measures related to buildings have been implemented for energy conservation and sustainability. Existing UHI mitigation and energy conservation strategies are outlined by Akbari et al. [6]; such as development of highly reflective (HR) materials, development of cool and 
green roof technologies, development of cool pavement technologies and urban trees that can decrease ambient and surface temperatures in cities. Furthermore, UHI mitigation leads to energy savings, improves urban air quality and ambient conditions, and helps to counter global warming (GW).

\subsection{State of Research on HR and Retro-Reflective Envelopes}

Among these technologies for UHI mitigation, HR envelopes are being researched globally $[7,8]$. A review showed that the HR roof can reduce the roof daily heat gain between $11 \%$ and $60 \%$, reduce the indoor air temperatures around $1-7^{\circ} \mathrm{C}$ and decrease daily cooling energy consumption between $1 \%$ and $80 \%$ [9]. A research of quantitative estimation on the impact of white reflective and colored reflective materials indicated that the reflective white roofs without insulation lead to net savings over a 10-year life-cycle cost analysis between $3.0 \$ / \mathrm{m}^{2}$ and $67.4 \$ / \mathrm{m}^{2}$ compared to gray roofs in cities in Mexico. When thermally insulated, reflective white roofs lead to positive net savings, just in warmer locations; such savings ranged between $0.1 \$ / \mathrm{m}^{2}$ and $13.6 \$ / \mathrm{m}^{2}$ [10]. In addition, a field measurement on the change in solar reflectivity of HR roofing sheet was implemented [11]. It showed that the solar reflectivity of the HR roofing sheet installed on the rooftop decreased by about 0.04 after approximately one-year exposure due to the dirt accumulated on the roof surface, and its solar reflectivity was restored after cleaning the roof surface with distilled water. In recent years, possible application of retro-reflective (RR) materials to building facades has been studied by many scholars [12-14]. It revealed that the RR envelope is more effective to mitigate UHI and increase urban albedo compared to the diffuse reflection of HR envelopes.

\subsection{Urbanization and Inter-Building Effect}

As the same time, substantial global trend has emerged to impede us from a more sustainable built environment. A report by the United Nations indicated that a significant shift in population from rural areas to urban areas will continue through 2050 [15]. The population in urban areas is predicted to increase by approximately $40 \%$ and the population in rural areas will decrease by about the same percentage. If the population in urban areas is increasing, it will be reasonable to expect the morphology of urban areas to involve tighter spatial interrelationships among buildings. When buildings evolved to be in closer proximity due to the increase of the urban population, the current modeling approaches that treat buildings as stand-alone entities may not accurately represent building energy performance because they often do not consider the close proximity of other buildings in an urban environment and the energy implications that this phenomenon could cause [16]. With consideration of the inter-building effect (IBE) on building energy use, a numerical simulation tool for predicting the influence of the outdoor thermal environment on building energy performance was proposed by He et al. [17]. This indicated that when assessing energy use of buildings, not only thermophysical properties of the external wall surface are considered, but also the impact of surrounding environment is taken into account. Other research on the IBE was implemented via analyzing the mutual shading among buildings by Shaviv and Yezioro [18]. It showed how to calculate the impact of shading on solar gains of building envelopes.

\subsection{Simulation}

Simulation tools offer powerful functionalities to predict and improve building energy consumption for both research and design purposes. EnergyPlus is an energy analysis and thermal load simulation engine distributed by the U.S. Department of Energy (DOE) and it has become a popular building energy performance simulation owing to its sophisticated and validated functions [19]. In order to understand such complex mutual impact of the IBE within spatially proximal buildings, the influence of mutual shading and mutual reflection within a network of buildings was disaggregated and quantified using EnergyPlus [20]. This showed that the shading effect caused by surrounding buildings plays a more significant role in terms of impact on energy consumption. In addition, a methodology for evaluating a building energy performance was proposed by enlarging the assessment 
perspective from a single building to a network of buildings [16]. It showed that buildings can mutually impact the energy dynamics of other buildings and this effect varies by climatological context and by season. The IBE analysis and the specific proposed methodology revealed energy requirement modeling inaccuracies of up to $42 \%$ in summer in Miami and up to $22 \%$ in winter in Minneapolis.

\subsection{Aims of This Research}

For the aim of evaluating the influence of the IBE and its relation with HR building envelopes on the building energy use, the analysis for five representative cities (Sapporo, Tokyo, Nagoya, Osaka, and Kagoshima) of Japan was implemented using "Building Energy Optimization (BEopt)" in this study, considering the annualized energy use, annualized energy related costs, and annualized utility bills of a simulated building over a setting building envelope lifetime of 15-year.

\section{Experiments}

\subsection{Simulated Building and Geographical Locations}

According to the building standard law of Japan, a three-story building with a gable roof (roof pitch of 6:12) was simulated as shown in Figure 1 in this study. Its construction area is approximately $92 \mathrm{~m}^{2}$, and its total floor area is approximately $273 \mathrm{~m}^{2}$. The orientation of the simulated building is south-north facing. In order to evaluate the influence of IBE and its relation with the HR building envelope on the energy use of buildings, the simulated building was defined for three different scenarios. Structures of the three simulated scenarios are detailed in Table 1. Scenario A is a simulated single building which is not surrounded by buildings and its envelope coated with a lowly-reflective (LR) brick material (solar reflectivity: 0.12) [21]; Scenario B is a simulated building which is surrounded by buildings on four sides and its envelope coated with a LR brick material the same as Scenario A; Scenario $C$ is a simulated building which is surrounded by buildings and its envelope coated with a brick material painted with HR paint (solar reflectivity: 0.7) [22]. In addition, a white color HR roofing sheet (solar reflectivity: 0.7) [23] is installed on the roofs for all three simulated scenarios. It is worth mentioning that all costs of materials applied to external walls and rooftops are more uniformly moderately priced than other building materials in the Japanese market. The left and right distance between two buildings must be more than $0.5 \mathrm{~m}$ according to the building standard law of Japan, thus the distance between two buildings is set to $2.5 \mathrm{~m}$ for Scenarios B and C in this study.
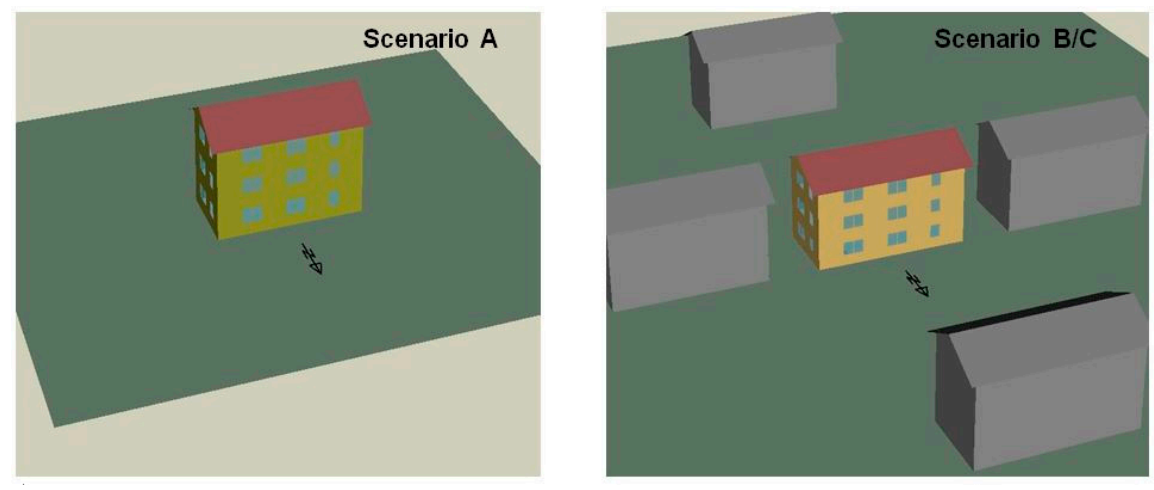

Figure 1. The simulated building (Scenario A: a single building without surrounding buildings and its envelope coated with LR materials; Scenario B: a building with surrounding buildings and its envelope coated with LR materials; and Scenario C: a building with surrounding buildings and its envelope covered with HR materials).

For cooling and heating equipment used in the simulated building, central air-conditioning (AC) was used for cooling in summer, and a gas furnace with an annual fuel utilization efficiency 
of $78 \%$ was used for heating in winter [24]. In addition, gas water heaters with an energy factor of 0.59 [25], and light-emitting diode (LED) lighting fixtures with an efficacy of $55 \mathrm{~lm} / \mathrm{W}$ were used [26]. Detailed conditions of equipment usage in the simulated building are shown in Table 2. This study focuses on the effect of the building coating structure and surrounding buildings on building energy use, thus, the effects of indoor human and equipment usage factors are not investigated. The same indoor human and equipment usage conditions are set for the three scenarios in this study.

The average consumer electricity price in Japan is $0.24 \$ / \mathrm{kWh}$ for the year 2016 [27]. The average consumer gas price in Japan is $0.89 \$ / \mathrm{m}^{3}$ for the year 2016 [28]. The homeowner costs calculated in this study assume a 15 -year mortgage at a $4.0 \%$ interest rate with a $2.4 \%$ general inflation rate and a $3.0 \%$ real discount rate, which is chosen as one of the common forms of housing loan in Japan.

Five representative cities of Japan were selected from high-latitude to low-latitude to analyze energy use of the simulated building in this study. The five representative cities are detailed in Table 3.

Table 1. Orientations and structures of three simulated scenarios.

\begin{tabular}{|c|c|c|c|}
\hline & $\begin{array}{l}\text { Scenario A: } \\
\text { Base } \\
\text { (Single Building with } \\
\text { LR Envelope) }\end{array}$ & $\begin{array}{l}\text { Scenario B: } \\
\text { Building Group } \\
\text { (IBE with LR Envelope) }\end{array}$ & $\begin{array}{l}\text { Scenario C: } \\
\text { Improved Building } \\
\text { (IBE with HR Envelope) }\end{array}$ \\
\hline Orientation & South-north facing & Same as Scenario A & Same as Scenario A \\
\hline Neighbors & None & $\begin{array}{l}\text { Left/Right at } 2.5 \mathrm{~m} \\
\text { Front/Back at } 8.0 \mathrm{~m}\end{array}$ & Same as Scenario B \\
\hline Roof & $\begin{array}{l}\text { Gypsum board + Hollow layer + } \\
\text { Ordinary concrete + Fiberglass batt } \\
+ \text { Mortar + Asphalt + White color } \\
\text { HR roofing sheet } \\
\square \text { Solar reflectivity: } 0.70 \\
\text { R-value of roof: } 3.0 \mathrm{~m}^{2} \mathrm{~K} / \mathrm{W} \text {; } \\
\mathbf{\square} \text { Cost per unit: } 12.5 \$ / \mathrm{m}^{2}\end{array}$ & Same as Scenario A & Same as Scenario A \\
\hline Window & $\begin{array}{l}\text { Window area: (Front/Back: } 15 \mathrm{~m}^{2} \text {; } \\
\text { Left/Right: } 8.5 \mathrm{~m}^{2} \text { ); Total } \\
\text { window-wall ratio: } 0.15 \text {; Low-E } \\
\text { double with U-value of } 2.1 \mathrm{~W} / \mathrm{m}^{2} \mathrm{~K}\end{array}$ & Same as Scenario A & Same as Scenario A \\
\hline
\end{tabular}

Table 2. Detailed conditions of equipment usage in simulated building.

\begin{tabular}{cc}
\hline Cooling Equipment & Central Air-Conditioning \\
\hline Heating equipment & Furnace (gas, $78 \%$ annual fuel utilization efficiency) \\
Space conditioning schedules & Cooling set point: $24.4^{\circ} \mathrm{C} ;$ Heating point: $21.7^{\circ} \mathrm{C} ;$ \\
Water heater & Humidity set point: $45 \%$; 24 -h conditioning \\
Lighting & Gas (energy factor: 0.59 ) \\
& Light-emitting diodes (LED efficacy: $55 \mathrm{~lm} / \mathrm{W}$ ) \\
\hline
\end{tabular}


Table 3. Details of five representative cities in Japan.

\begin{tabular}{|c|c|c|c|c|}
\hline City & $\begin{array}{l}\text { Location } \\
\text { (Latitude, } \\
\text { Longitude) }\end{array}$ & Climate & $\begin{array}{l}\text { Average High } \\
\text { Temperature } \\
\left({ }^{\circ} \mathrm{C}\right) \text { (August) }\end{array}$ & $\begin{array}{l}\text { Average Low } \\
\text { Temperature } \\
\left({ }^{\circ} \mathrm{C}\right) \text { (January) }\end{array}$ \\
\hline Sapporo & $43.1^{\circ} \mathrm{N}, 141.4^{\circ} \mathrm{E}$ & $\begin{array}{l}\text { Humid continental climate with a wide } \\
\text { range of temperature between the } \\
\text { summer and winter }\end{array}$ & 26.4 & -7.0 \\
\hline Tokyo & $35.7^{\circ} \mathrm{N}, 139.9^{\circ} \mathrm{E}$ & $\begin{array}{l}\text { Humid subtropical climate zone with hot } \\
\text { humid summers and generally mild } \\
\text { winters with cool spells }\end{array}$ & 30.8 & 0.9 \\
\hline Nagoya & $35.2^{\circ} \mathrm{N}, 136.9^{\circ} \mathrm{E}$ & $\begin{array}{l}\text { Humid subtropical climate with hot } \\
\text { summers and cool winters }\end{array}$ & 32.8 & 0.8 \\
\hline Osaka & $34.7^{\circ} \mathrm{N}, 135.5^{\circ} \mathrm{E}$ & $\begin{array}{l}\text { Humid subtropical climate zone with } \\
\text { four distinct seasons }\end{array}$ & 33.4 & 2.8 \\
\hline Kagoshima & $31.6^{\circ} \mathrm{N}, 130.5^{\circ} \mathrm{E}$ & $\begin{array}{l}\text { Humid subtropical climate with hot, wet } \\
\text { summers and cool, relatively dry winters }\end{array}$ & 32.5 & 4.6 \\
\hline
\end{tabular}

\subsection{BEopt}

An analysis tool, BEopt, was used to analyze the energy consumption of the simulated building with three different scenarios. It provides detailed simulation-based analysis based on specific house characteristics, such as size, architecture, occupancy, vintage, location, and utility rates. Discrete envelope and equipment options, reflecting realistic construction materials and practices, are evaluated. It can be used to analyze both new construction and existing home retrofits, as well as single-family detached and multi-family buildings, through evaluation of single building designs, parametric sweeps, and cost-based optimizations [29]. The BEopt analysis method was developed to determine the least-cost path to zero net energy (ZNE) homes, based on evaluating the marginal costs of different combinations of energy efficiency and renewable-energy options [30]. It is known that the sequential search technique has several advantages. First, it finds intermediate optimal points all along the path, i.e., minimum-cost building designs at different target energy saving levels, not just the global optimum or the ZNE optimum. Second, discrete rather than continuous, building options are to be evaluated to reflect realistic construction options. Third, some near-optimal alternative designs are identified (that can serve as a starting point for generating a more complete set by permutations).

This method has recently been applied to determine the most cost-effective approaches to achieve the near-term and long-term performance targets for the DOE Building America Program [31]. The BEopt calls the DOE2 and TRNSYS simulation programs and automates the optimization process (see Figure 2). The optimization method involves sequentially searching for the most cost-effective option across a range of categories (wall type, ceiling type, window glass type, HVAC type, etc.) to identify optimal building designs along the path to ZNE.

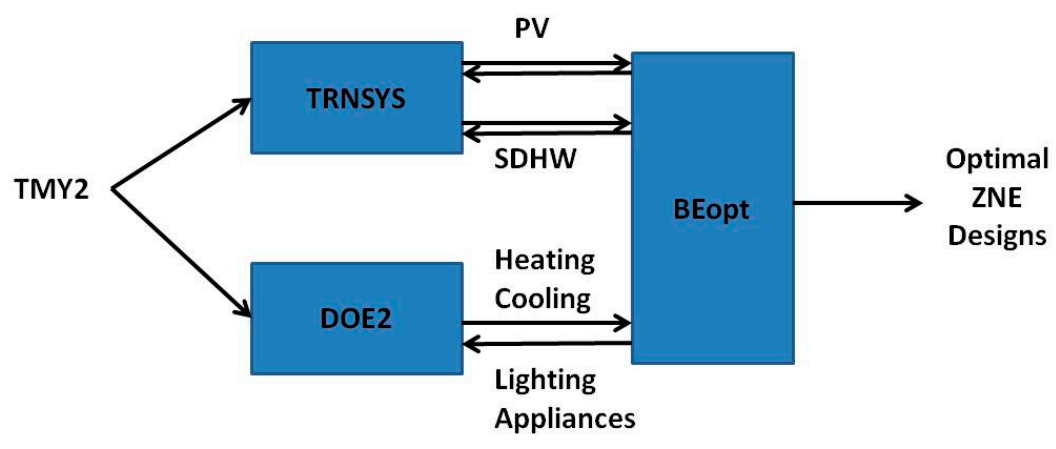

Figure 2. Optimization with multiple simulation programs. 


\subsection{Input and Output Definition}

According to the definition of BEopt 2.6.0.0 [32], the input items in this study include: building (geographical location, climate, geometry, orientation, neighbors, floor area, etc.), wall structure (insulation, etc.), roof structure, thermal mass, windows, space conditioning, water heating, lighting, appliances \& fixtures, local mortgage, utility rates, etc. (see Figure 3).

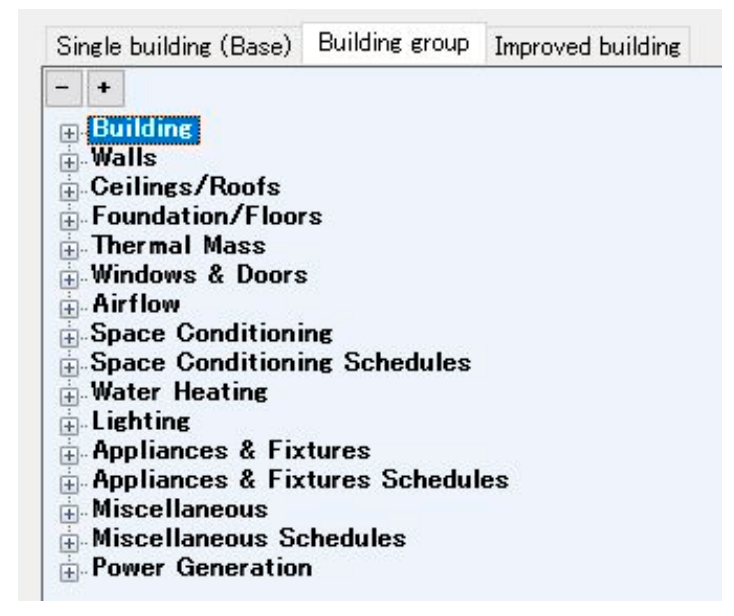

Figure 3. Input items interface of BEopt software.

The output items used in this study are defined as following:

- Annualized source energy: is the total energy consumed to meet the energy needs of the building, including that used in transmission, delivery and production, in MMBtu/yr or $\mathrm{kWh} / \mathrm{yr}$.

- Annualized site energy: is electricity or fuel consumed within a property boundary (e.g. a home), which is reflected in the utility bills at the site, in MMBtu/yr or kWh/yr.

- Annualized utility bills: is divided into two parts, the gas charge and the electricity charge, in $\$ / y$ r.

- Annualized energy related cost: is calculated by annualizing the energy related cash flows over the analysis period, in $\$ / y r$.

The annualized cost is then subtracted from the reference for every cash flow but utility bills (i.e., the values displayed in the cost/energy graph are full annualized utility bills plus incremental annualized values for every other cash flow). The annualized energy related cost is calculated with Equation (1),

$$
C_{e}=U+C_{m}+C_{r}+C_{e t c}
$$

where $C_{e}$ is the annualized energy related cost, $\$ / \mathrm{yr} ; U$ is the annualized utility bills, $\$ / \mathrm{yr} ; C_{m}$ is the incremental mortgage cost, $\$ / \mathrm{yr} ; C_{r}$ is the incremental replacement costs, $\$ / \mathrm{yr}$; and $C_{e t c}$ is the other incremental costs, $\$ / y$.

Thus, in general, the $C_{e}$ will be greater than $U$. However, this will not be true if any of the incremental cash flows are negative. If the incremental costs $\left(C_{m}, C_{r}\right.$ and $\left.C_{e t c}\right)$ are ignored, the $C_{e}$ will be equal to $U$.

\section{Results}

\subsection{Annualized Energy Use and Energy Savings}

The annualized source energy use and annualized site energy use of the simulated building with three different scenarios in five representative cities of Japan are calculated and detailed in Table 4 . As an example, the annualized source energy use and annualized site energy use of the simulated building with three different scenarios for Tokyo are shown in Figures 4 and 5, respectively. 


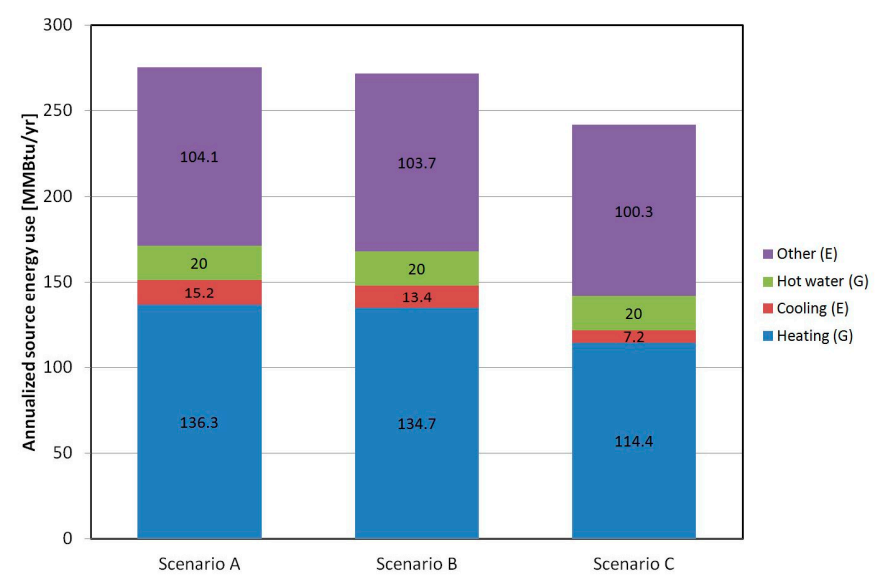

Figure 4. Annualized source energy (E: electricity and G: gas) use of simulated building with three different scenarios in Tokyo (1 MMBtu $=293 \mathrm{kWh})$.

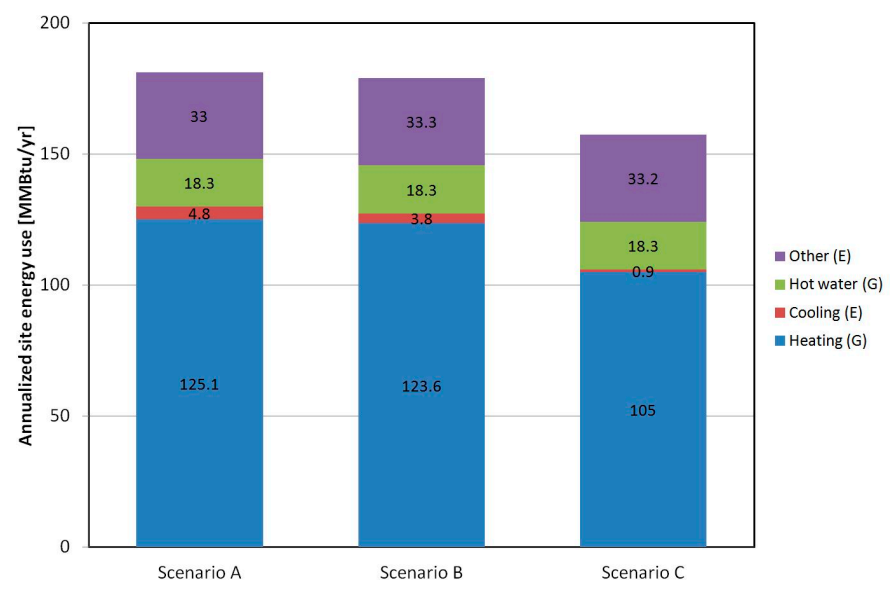

Figure 5. Annualized site energy (E: electricity and G: gas) use of simulated building with three different scenarios in Tokyo (1 MMBtu $=293 \mathrm{kWh})$.

Compared to the total annualized source energy use of Scenario A (detailed in Table 4) in five representative cities of Japan, that of Scenario B in Kagoshima decreased the largest, about 2.5\% (cooling: 9.4\%; heating: 1.3\%), followed by Nagoya, Osaka, Tokyo, and Sapporo. Compared to the total annualized site energy use of Scenario A (in Table 4), that of Scenario B in Nagoya decreased the most, by about $2.1 \%$ (cooling: $10.2 \%$; heating: $2.3 \%$ ), followed by Kagoshima, Osaka, Tokyo, and Sapporo.

Compared to the total annualized source energy use of Scenario A (detailed in Table 4) in five representative cities of Japan, that of Scenario C in Kagoshima decreased the most, by about 14.7\% (cooling: $42.9 \%$; heating: $17.7 \%$ ), followed by Nagoya, Osaka, Tokyo, and Sapporo. Compared to the total annualized site energy use of Scenario A (in Table 4), that of Scenario C in Nagoya decreased the most, by about $14.5 \%$ (cooling: $43.2 \%$; heating: $17.7 \%$ ), followed by Kagoshima, Osaka, Tokyo and, Sapporo. 
Table 4. Annualized source energy use and site energy use (for total, heating, and cooling) of a simulated building with three different scenarios in five representative cities of Japan.

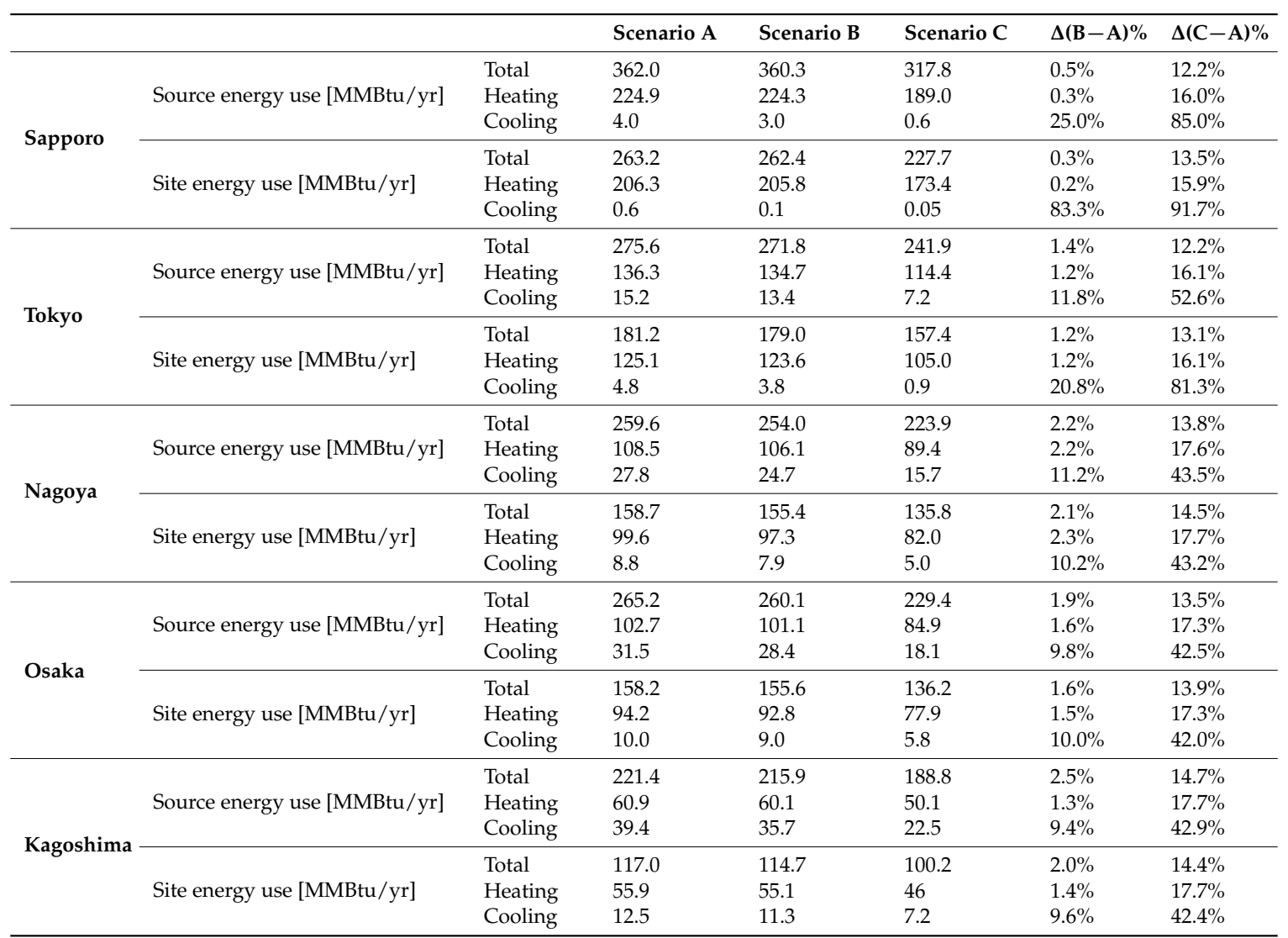

$(1 \mathrm{MMBtu}=293 \mathrm{kWh})$.

\subsection{Annualized Energy Related Costs and Annualized Utility Bills}

According to Section 2.3, the annualized energy related costs can be calculated using Equation (1). In this study, the incremental costs $\left(C_{m}, C_{r}\right.$ and $\left.C_{e t c}\right)$ were ignored; thus, the annualized energy-related cost is equal to the annualized utility bill. The annualized energy-related costs, or annualized utility bills (electricity charge and gas charge), of the simulated building in three different scenarios in five representative cities of Japan is shown in Table 5.

Table 5. Annualized energy-related costs or annualized utility bills (electricity charge and gas charge) of a simulated building with three different scenarios in five representative cities of Japan.

\begin{tabular}{|c|c|c|c|c|c|c|}
\hline & $\begin{array}{l}\text { Annualized Energy Related Costs } \\
\text { or Annualized Utility Bills [\$/yr] }\end{array}$ & Scenario A & Scenario B & Scenario C & $\Delta(\mathrm{B}-\mathrm{A}) \%$ & $\Delta(\mathrm{C}-\mathrm{A}) \%$ \\
\hline \multirow{3}{*}{ Sapporo } & Total & 3561 & 3545 & 3162 & $0.4 \%$ & $11.2 \%$ \\
\hline & Gas & 2127 & 2122 & 1818 & $0.2 \%$ & $14.5 \%$ \\
\hline & Electricity & 1242 & 1231 & 1163 & $0.9 \%$ & $6.4 \%$ \\
\hline \multirow{3}{*}{ Tokyo } & Total & 2827 & 2788 & 2512 & $1.4 \%$ & $11.1 \%$ \\
\hline & Gas & 1345 & 1331 & 1156 & $1.0 \%$ & $14.1 \%$ \\
\hline & Electricity & 1291 & 1265 & 1163 & $2.0 \%$ & $9.9 \%$ \\
\hline \multirow{3}{*}{ Nagoya } & Total & 2720 & 2664 & 2376 & $2.1 \%$ & $12.6 \%$ \\
\hline & Gas & 1093 & 1072 & 928 & $1.9 \%$ & $15.1 \%$ \\
\hline & Electricity & 1435 & 1400 & 1255 & $2.4 \%$ & $12.5 \%$ \\
\hline \multirow{3}{*}{ Osaka } & Total & 2789 & 2737 & 2440 & $1.9 \%$ & $12.5 \%$ \\
\hline & Gas & 1061 & 1047 & 908 & $1.3 \%$ & $14.4 \%$ \\
\hline & Electricity & 1536 & 1497 & 1340 & $2.5 \%$ & $12.8 \%$ \\
\hline \multirow{3}{*}{ Kagoshima } & Total & 2415 & 2358 & 2086 & $2.4 \%$ & $13.6 \%$ \\
\hline & Gas & 669 & 662 & 577 & $1.0 \%$ & $13.8 \%$ \\
\hline & Electricity & 1554 & 1503 & 1317 & $3.3 \%$ & $15.3 \%$ \\
\hline
\end{tabular}


The results (Table 5) show that the annualized energy related costs or annualized utility bills in Sapporo is the largest, approximately 3561 \$/yr (gas charge: 2127 \$/yr; electricity charge: 1242 \$/yr) for Scenario A, approximately 3545 \$/yr (gas charge: 2122 \$/yr; electricity charge: 1231 \$/yr) for Scenario B, and approximately $3162 \$ / y r$ (gas charge: 1818 \$/yr; electricity charge: 1163 \$/yr) for Scenario C, followed by Tokyo, Osaka, Nagoya and Kagoshima.

As an example of Tokyo, the annualized utility bills of the simulated building with three different scenarios are shown in Figure 6.

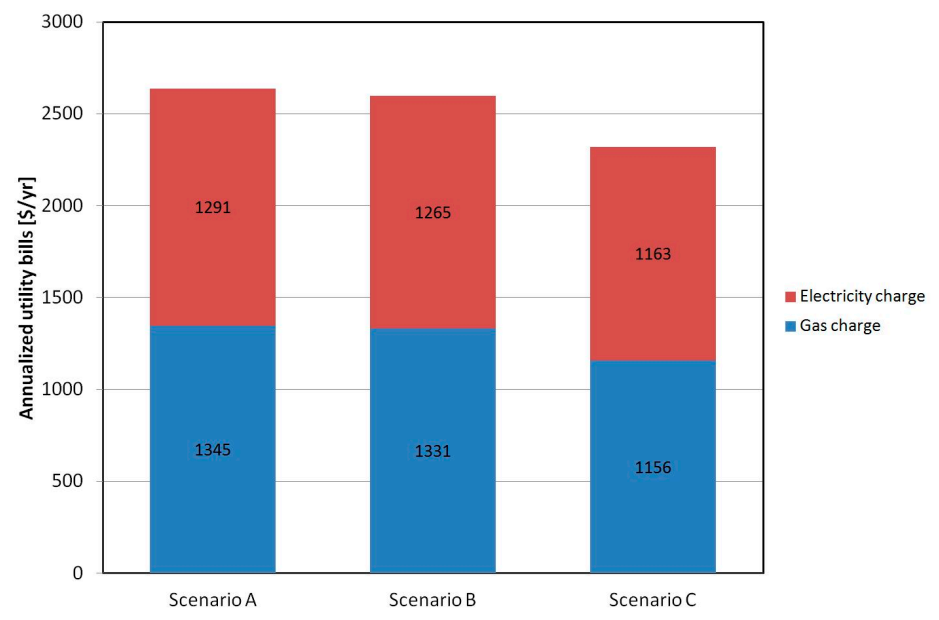

Figure 6. Annualized utility bills of the simulated building with three different scenarios in Tokyo.

Compared to the annualized utility bills (or annualized energy related costs) of Scenario A (detailed in Table 5) in five representative cities of Japan, that of Scenario B in Kagoshima decreased the largest, about $2.4 \%$ (electricity charge: $3.3 \%$; gas charge: $1.0 \%$ ), followed by Nagoya, Osaka, Tokyo, and Sapporo.

Compared to the annualized utility bills of Scenario A (in Table 5) in five representative cities of Japan, that of Scenario C in Kagoshima decreased the most, by about 13.6\% (electricity charge: 15.3\%; gas charge: $13.8 \%$ ), followed by Nagoya, Osaka, Tokyo. and Sapporo.

\section{Discussion}

\subsection{Influence of IBE with LR Building Envelopes on Energy Use}

Through the comparison between Scenario A (a single building with LR building envelope) and Scenario B (IBE with LR building envelope), we can see that Scenario B with neighboring buildings can contribute to annualized energy savings and annualized utility bill savings, compared to a single building (Scenario A). It is considered that the IBE including mutual shading and mutual reflection within a network of buildings is effective to reduce energy use [20]. In addition, we can see that the lower the latitude of Japanese cities, the larger the annualized energy savings, annualized energy related cost savings, and annualized utility bill savings, due to the impact of IBE. However, this changing trend is not absolute: it also depends on regional climate conditions and other factors.

\subsection{Influence of IBE with HR Building Envelopes on Energy Use}

Through the comparison between Scenario B (IBE with the LR building envelope) and Scenario C (IBE with HR building envelope), we can see that the IBE with the HR building envelope (Scenario C) can better contribute to annualized energy savings and annualized utility bill savings, compared to IBE with LR building envelope (Scenario B). The reason for this is considered to be that the HR building envelope can reflect more sunlight to the surrounding environment than the LR building envelope, thus, the solar radiation absorbed by the HR building envelope will be less and the heat 
transfer from the exterior wall to the interior wall will also be less, resulting in a cooling load reduction during summer. As the reflected sunlight from the HR envelope and the mutual reflection with the surrounding buildings will heat the ambient air, the outdoor radiant temperature in Scenario $C$ will be higher than that in Scenario B, thus, the heating load during winter also decreased in this study.

In addition, it also indicated that the lower the latitude of Japanese cities, the larger the annualized energy savings and the annualized utility bill savings, due to the building envelopes with HR performance. The reason is considered that the HR envelopes are more effective in terms of reducing annualized thermal loads and energy use in locations of Japan with lower latitudes and hotter summers, according to previous research [33].

\subsection{Comparison of Annualized Energy Related Cost}

Comparing the annualized energy related cost of the simulated building with three different scenarios in five representative cities of Japan, it showed that the annualized energy related cost of Scenario A is the largest, followed by Scenario B, and Scenario C has the lowest annualized energy related cost for each city of Japan. The annualized energy related cost of the simulated building decreased when varying the city from high-latitude to low-latitude for each scenario. The influence of IBE within a network of buildings on annualized energy related cost became a bit greater when varying the Japan cities from high-latitude to low-latitude. The IBE with HR building envelopes is the most effective to reduce the annualized energy-related costs among three simulated scenarios.

\subsection{Model Verification}

In order to verify the analyzed results obtained by BEopt, we compared the annualized site energy use between actual office buildings [34] and the simulated building in five representative cities. The result (Figure 7) showed that the average annualized site energy use of actual office buildings is about $90 \mathrm{kWh} / \mathrm{m}^{2}$-yr higher than that of the simulated building.

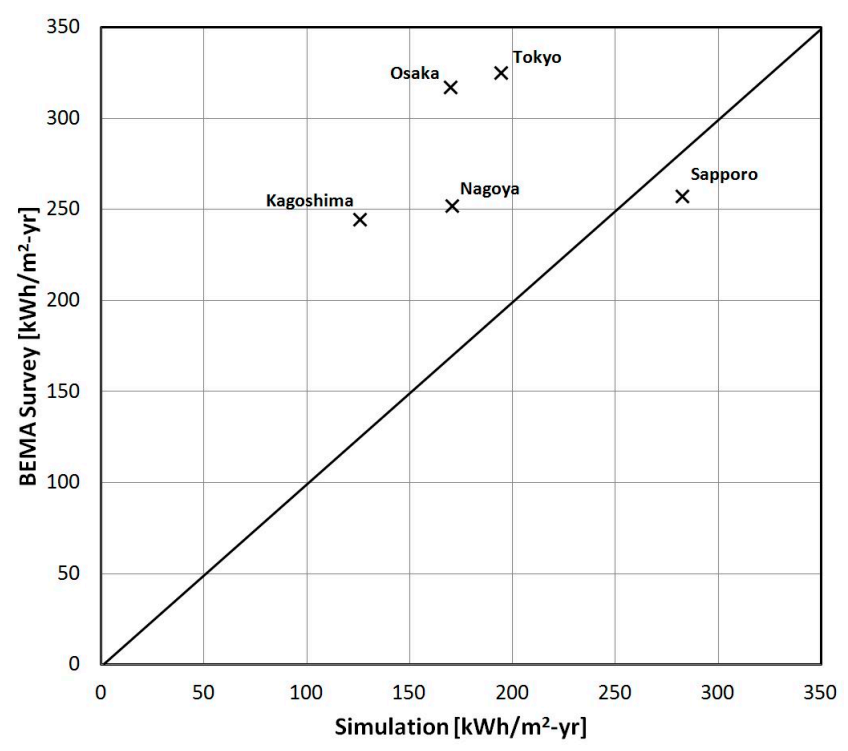

Figure 7. Comparison of annualized site energy use between BEMA survey and BEopt's simulation results for five representative cities of Japan.

The deviation between the actual survey and simulation is considered to be due to the following reasons: (i) the simulated building construction is not completely consistent with the actual building construction, the average floor space of the actual surveyed office buildings was $19340 \mathrm{~m}^{2}$ over 444 cases, much larger than the simulated case of $273 \mathrm{~m}^{2}$. The much smaller simulated three-floor building gains far more heating from solar radiation per square meter of floor space than the tall 
buildings with more floors in the survey; and (ii) the usage conditions of the actual buildings are likely different from the simulated building, i.e., the number of people in the building, use of equipment in the building, not using 24-h air conditioning as in the simulation, and other human factors, etc.

According to the above problems, a much deeper verification should be carried out by importing the measured energy use data of the actual buildings respectively in five representative cities of Japan, with consideration of the coincidence of actual building and simulated building, and the influence of human behavior factors, etc.

\section{Conclusion and Future Work}

In order to evaluate the influence of the IBE with HR building envelope on building energy use, the BEopt analysis method has been used to evaluate the annualized energy use, annualized energy related costs and annualized utility bills of simulated building with three different scenarios located in five representative cites of Japan in this study.

The comparison between Scenario A (base: a single building with LR building envelope) and Scenario B (IBE with LR building envelope) by BEopt analysis indicated that the building with surrounding buildings is more effective than that without surrounding buildings in terms of reducing annualized energy use, annualized utility bills and annualized energy related costs for five representative cities of Japan. Thus, it is necessary to consider the influence of IBE (Scenario B), including mutual shading and mutual reflection within a network of buildings when evaluating the energy consumption of buildings. In addition, it showed that the annualized energy savings, annualized energy related cost savings, and annualized utility bill savings increased when varying the Japanese cities from high-latitude to low-latitude, due to the impact of IBE. However, this changing trend is not absolute: it also depends on regional climate conditions and other factors.

The comparison between Scenario B (IBE with LR building envelope) and Scenario C (IBE with HR building envelope) demonstrated that the IBE with HR building envelope can better contribute to annualized energy savings and annualized utility bill savings in five representative cities of Japan.

The future work will focus on evaluating the influence of IBE with HR envelope design on the outdoor micro-environment within a network of buildings while, at the same time, monitoring the energy use of actual buildings. The increasing use of solar panels on rooftops could influence the results. Here, the rooftop parameters were kept uniform in all three scenarios, but net heat flux through the roof could change. Furthermore, the influence of wind fields around buildings, humidity, etc., on the building energy use will also evaluated.

Acknowledgments: The authors are sincerely grateful to the BEopt Principal Investigator: Craig Christensen (National Renewable Energy Laboratory) for developing the advanced building energy optimization software.

Author Contributions: All authors contributed equally in the preparation of this manuscript.

Conflicts of Interest: The authors declared that there is no conflict of interest with respect to the research, authorship, and/or publication of this article.

\section{References}

1. Pérez-Lombard, L.; Ortiz, J.; Pout, C. A review on buildings energy consumption information. Energy Build. 2008, 40, 394-398.

2. U.S. Department of Energy, Energy Efficiency and Renewable Energy. Energy Efficiency Trends in Residential and Commercial Buildings. 2008. Available online: https:/ /www1.eere.energy.gov/buildings/publications/ pdfs/corporate/bt_stateindustry.pdf (accessed on 28 October 2017).

3. Hui, S.C.M. Low energy building design in high density urban cities. Renew. Energy 2001, 24, 627-640. [CrossRef]

4. International Energy Agency. Energy Efficiency. Available online: http://www.iea.org/aboutus/faqs/ energyefficiency (accessed on 14 March 2017).

5. Ministry of Economy, Trade and Industry. Carbon dioxide emissions information. Available online: http:/ / www.meti.go.jp (accessed on 14 March 2017). 
6. Akbari, H.; Cartalis, C.; Kolokotsa, D.; Muscio, A.; Pisello, A.L.; Rossi, F.; Santamouris, M.; Synnefa, A.; Wong, N.H.; Zinzi, M. Local climate change and urban heat island mitigation techniques-The state of the art. J. Civ. Eng. Manag. 2016, 22, 1-16. [CrossRef]

7. Gobakis, K.; Kolokotsa, D.; Maravelaki-Kalaitzaki, N.; Perdikatsis, V.; Santamouris, M. Development and analysis of advanced inorganic coatings for buildings and urban structures. Energy Build. 2016, 89, 196-205. [CrossRef]

8. Cozza, E.S.; Alloisio, M.; Comite, A.; di Tanna, G.; Vicini, S. NIR-reflecting properties of new paints for energy-efficient buildings. Sol. Energy 2015, 116, 108-116. [CrossRef]

9. Hernández-Pérez, I.; Álvarez, G.; Xamán, J.; Zavala-Guillén, I.; Arce, J.; Simá, E. Thermal performance of reflective materials applied to exterior building components-A review. Energy Build. 2014, 80, 81-105. [CrossRef]

10. Hernández-Pérez, I.; Xamán, J.; Macías-Melo, E.V.; Aguilar-Castro, K.M. Chapter 4: Reflective Materials for Cost-Effective Energy-Efficient Retrofitting of Roofs. In Cost-Effective Energy Efficient Building Retrofitting; Woodhead Publishing Limited: Cambridge, UK, 2017; pp. 119-139.

11. Yuan, J.; Emura, K.; Sakai, H. Evaluation of the Solar Reflectance of Highly Reflective Roofing Sheets Installed on Roofs. J. Build. Phys. 2012, 37, 170-184. [CrossRef]

12. Nishioka, M.; Inoue, S.; Sakai, K. Retroreflective properties calculating method based on geometrical-optics analysis. J. Environ. Eng. 2008, 73, 1249-1254. (In Japanese) [CrossRef]

13. Rossi, F.; Castellani, B.; Presciutti, A.; Morini, E.; Filipponi, M.; Nicolini, A.; Santamouris, M. Retroreflective façades for urban heat island mitigation: Experimental investigation and energy evaluations. Appl. Energy 2015, 145, 8-20. [CrossRef]

14. Yuan, J.; Farnham, C.; Emura, K. Development of a retro-reflective material as building coating and evaluation on albedo of urban canyons and building heat loads. Energy Build. 2015, 103, 107-117. [CrossRef]

15. United Nations. World Urbanization Prospects: The 2007 Revision Population Database, Panel 1: Urban and Rural Areas. Available online: http:/ / esa.un.org/unup/ (accessed on 15 March 2017).

16. Pisello, A.L.; Taylor, J.E.; Xu, X.; Cotana, F. Inter-building effect: Simulating the impact of a network of buildings on the accuracy of building energy performance predictions. Build. Environ. 2012, 58, 37-45. [CrossRef]

17. He, J.; Hoyano, A.; Asawa, T. A numerical simulation tool for predicting the impact of outdoor thermal environment on building energy performance. Appl. Energy 2009, 86, 1596-1605. [CrossRef]

18. Shaviv, E.; Yezioro, A. Analyzing mutual shading among buildings. Sol. Energy 1997, 59, 83-88. [CrossRef]

19. U.S. Department of Energy. EnergyPlus Engineering Reference: The Reference to EnergyPlus Calculations. Available online: https:/ / energyplus.net/ (accessed on 15 March 2017).

20. Han, Y.; Taylor, J.E. Disaggregate Analysis of the Inter-Building Effect in a Dense Urban Environment. Energy Procedia 2015, 75, 1348-1353. [CrossRef]

21. Brick Exterior Walls. Available online: http:/ / ansin-tosou.com/gaiheki/renga.html (accessed on 15 March 2017).

22. Highly Reflective Exterior Wall Materials. Available online: http://www.radiant88.com/500/50040/ (accessed on 16 March 2017).

23. Highly Reflective Roofing Sheet. Available online: http://ansin-tosou.com/gaiheki/renga.html (accessed on 15 March 2017).

24. Gas Furnace. Available online: http:/ / rinnai.jp/products/living/fan_heater/fh (accessed on 16 March 2017).

25. Gas Water Heater. Available online: http:/ / rinnai.jp/products/waterheater/gas/ (accessed on 16 March 2017).

26. Light-Emitting Diode Lighting. Available online: http://www.mitsubishielectric.co.jp/ldg/ja/products / lighting/lineup/fixture/index.html (accessed on 16 March 2017).

27. Calculation of Electricity Rate in Japan. Available online: http://www.denki-keisan.info (accessed on 16 March 2017).

28. Calculation of Gas Rate in Japan. Available online: https:/ /wwwe5.osakagas.co.jp/custserv/ryokinhyo1001.html (accessed on 16 March 2017).

29. National Renewable Energy Laboratory, BEopt. Available online: https://beopt.nrel.gov (accessed on 6 October 2017).

30. Christensen, C.; Barker, G.; Horowitz, S. A Software Tool for Identifying Optimal Building Designs on the Path to Zero Net Energy. In Proceedings of the Solar 2004 Conference: Including Proceedings of 33rd ASES Annual Conference, Proceedings of 29th National Passive Solar Conference, Portland, OR, USA, 11-14 July 2004. 
31. Anderson, R.; Christensen, C.; Horiwitz, S. Analysis of Residential Systems Targeting Least-Cost Solutions Leading to Net Zero Energy Homes. In Proceedings of the 2006 ASHRAE Annual Meeting, Quebec City, QC, Canada, 24-28 June 2006.

32. National Renewable Energy Laboratory. BEopt 2.6.0.0 Help. 2006. Available online: https://beopt.nrel.gov/ sites/beopt.nrel.gov / files/help/prntdoc/BEopt.pdf (accessed on 3 April 2017).

33. Yuan, J.; Farnham, C.; Emura, K.; Alam, A. Proposal for optimum combination of reflectivity and insulation thickness of building exterior walls for annual thermal load in Japan. Build. Environ. 2016, 103, 228-237. [CrossRef]

34. Report on Building Energy Consumption Survey; 36th Report; The Building-Energy Manager's Association of Japan (BEMA): Tokyo, Japan, 2014.

2017 by the authors. Licensee MDPI, Basel, Switzerland. This article is an open access article distributed under the terms and conditions of the Creative Commons Attribution (CC BY) license (http:// creativecommons.org/licenses/by/4.0/). 